\title{
Delicate seafloor landforms reveal past Antarctic grounding-line retreat of kilometers per year
}

Authors: J. A. Dowdeswell*11, C. L. Batchelor ${ }^{1,2}$, A. Montelli ${ }^{1}$, D. Ottesen ${ }^{3}$, F. D. W. Christie $^{1}$, E. K. Dowdeswell ${ }^{1}$, J. Evans ${ }^{4}$

\section{Affiliations:}

${ }^{1}$ Scott Polar Research Institute, University of Cambridge, Cambridge, UK.

${ }^{2}$ Norwegian University of Science and Technology, Trondheim, Norway.

${ }^{3}$ Geological Survey of Norway, Trondheim, Norway.

${ }^{4}$ Department of Geography, Loughborough University, Loughborough, UK.

10

\begin{abstract}
A suite of grounding-line landforms on the Antarctic seafloor, imaged at unprecedented sub-meter horizontal resolution from an autonomous underwater vehicle, enables calculation of ice-sheet retreat rates from a complex of grounding-zone wedges on the Larsen continental shelf, western Weddell Sea. The landforms are delicate sets of up to 90 15 ridges, $<1.5 \mathrm{~m}$ high and spaced $20-25 \mathrm{~m}$ apart. We interpret these ridges as the product of squeezing up of soft sediment during the rise and fall of the ice-shelf grounding line during successive tidal cycles. Each ridge is preserved as the grounding line retreats. Grounding-line retreat rates of $40-50 \mathrm{~m} /$ day $(>10 \mathrm{~km} / \mathrm{yr}$ ) are inferred during regional deglaciation of the Larsen shelf after the Last Glacial Maximum. If repeated today, such rapid mass loss to the 20 ocean would have clear implications for increasing the rate of global sea-level rise.
\end{abstract}

One Sentence Summary: Submarine landform patterns suggest past Antarctic ice-sheet retreat rates much faster than modern satellite observations. 
Main Text: The ice shelves fringing about $75 \%$ of the Antarctic Ice Sheet represent a highly sensitive interface between ice and ocean, with potential for rapid grounding-line retreat and associated mass loss from the parent ice sheet $(1,2)$. It is not known, however, whether modern satellite-derived grounding-line retreat rates of tens to hundreds of meters per year, acquired over a time-window of about 30 years at most $(3,4)$, are representative of the maximum possible magnitude of retreat in, for example, West Antarctica's Pine Island Bay.

An ice-sheet grounding zone is the region over which seaward-flowing ice decouples from its underlying bed and becomes a freely-floating ice shelf; the instantaneous, tidally modulated junction between grounded ice, the seafloor and the resulting sub-ice shelf oceanwater cavity beyond is known as the 'grounding line' (5). The former grounding zone is often identified on high-latitude continental shelves by the presence of sedimentary depositional centres, grounding-zone wedges (GZWs), which provide a well-preserved geological archive of the transition zone between grounded ice sheets and floating ice shelves (5-7). GZWs build up predominantly through delivery of soft deforming sediments from the ice-sheet interior to the grounding zone along a line source. There is little space for vertical accretion in the restricted cavities immediately beyond the grounding zone (8) and GZWs are therefore typically subdued, asymmetrical features on the seafloor; they generally have a steeper icedistal face of a few degrees in slope angle and a more extensive ice-proximal portion often less than one degree $(5,7)$. GZW volumes can be up to several cubic kilometers, with the rate of formation depending on sediment supply and the duration of any still-stand during regional grounding-line retreat $(5,9)$.

We investigate, using an autonomous underwater vehicle (AUV) (10), the morphology and shallow stratigraphy of an $\sim 9 \mathrm{~km}^{2}$ area of five GZWs within a 40 by $10 \mathrm{~km}$ grounding-zone complex preserved after ice retreat beneath about $500 \mathrm{~m}$ of water on the continental shelf 
offshore of Larsen Inlet, eastern Antarctic Peninsula (Figs. 1, 2) (11). Multibeam echosounder data from the AUV are unprecedented in horizontal resolution at a few tens of centimeters (Materials and Methods), representing a step-change in our ability to observe fine-scale landforms preserved on the seafloor and to understand the highly sensitive setting of a former ice-sheet grounding zone and the processes operating there. The GZWs were deposited during deglaciation of the NE Antarctic Peninsula continental shelf following the Last Glacial Maximum (LGM), probably before the minimum age for the transition from grounded ice to ice shelf in the inner Larsen-A embayment at 10,700 cal. yr BP (derived by relative paleomagnetic intensity dating of core KC023, Fig. 1a (11-13)). They have remained almost undisturbed since ice retreat except for a thin drape of hemipelagic sediment (Fig. 2). Surface-morphological evidence (Fig. 2a) and shallow acoustic stratigraphy (Fig. 2c, d)

60 demonstrate that the GZWs cross-cut one another, providing a relative chronology for formation (Fig. 2b, inset). Heights varying between about 10-20 m mark the outer edges of GZWs 3, 4 and 5, and, together with limited acoustic-stratigraphic evidence (Fig. 2c, d), imply that the depocenters are approximately 10 to $20 \mathrm{~m}$ thick. Their asymmetry (Fig. 2a, d) is typical of over $100 \mathrm{GZWs}$ identified elsewhere in the polar continental-shelf record $(5,7)$. GZWs a and 2-5 rest on an older surface (labelled 1 in Fig. 2b) that includes streamlined landforms (Fig. 2a), and nearby cores VC318 and VC247 (Fig. 1a) contain soft (<8 kPa) diamictic subglacial traction till that has undergone deformation $(11,14)$. These elongate sedimentary features, which are interpreted as mega-scale glacial lineations (MSGLs) (Fig. 2a, e, f), are orientated in the direction of regional ice flow (Fig. 1a). The presence of MSGLs implies formation subglacially in soft sediments beneath actively flowing and probably fastflowing ice before and during GZW deposition $(15,16)$. In addition, the ice-distal margin of the GZWs, marking former ice-sheet grounding zones, contains a number of lobate forms 50- 
$100 \mathrm{~m}$ long (Fig. 2e, f) that are interpreted as debris flows demonstrating wedge progradation as deformation till was delivered to the grounding line by active ice.

75 On the low-gradient GZW surfaces a complex assemblage of fine-scale landforms is present, imaged at sub-meter resolution (Fig. 2a). The features are of two types forming the appearance of 'ladders' with numerous 'rungs'. The sides of each 'ladder' are linear features typically 2-4 m high, hundreds of meters long, spaced 50-200 m apart and orientated subparallel to the past ice-flow direction; they are interpreted as MSGLs. The MSGLs are formed within an acoustically semi-transparent unit that is overlain by a thin $(c .1 \mathrm{~m})$ drape of sediment (Fig. 2c, d). Overprinting the MSGLs are sets of delicate transverse-to-flow ridges or 'rungs' that are typically $<0.5 \mathrm{~m}$ high and spaced about 20-25 m apart (Table S1). These rungs are of relatively uniform morphology, with many having a steeper ice-distal side (Fig. $3 b-e)$.

This delicate submarine glacial landform assemblage, which we term 'ladder and rung topography', covers almost the whole imaged area of each GZW (Figs. 2a, 3). A maximum of 90 rungs has been identified on GZW 4 (Fig. 3; Table 1). Although the rungs have greater seafloor expression in the depressions between MSGL crests, they can often be traced across the intervening and larger MSGLs, and series of up to 50 are continuous right across several of the GZWs (Fig. 3a). This implies that the rungs are younger than the larger flow-parallel MSGLs and the GZWs. The rungs are interpreted to have formed during retreat of the icesheet grounding line across the GZW surface. Their regular spacing implies a cyclical formation mechanism.

Regularly spaced small transverse ridges have been observed occasionally at coarser resolution on high-latitude continental shelves and in fjords $(17,18)$. Graham et al. (18), for example, used an AUV to image distinctive sets of ridges along several individual transects beneath the floating tongue of Pine Island Glacier, West Antarctica, at $2 \mathrm{~m}$ grid-cell size. The 
dimensions, spacing, and plan-view and cross-sectional geometry of similar ridges observed on several Antarctic shelves are compared in Table S1. Many of the sets of small ridges,

100 which have been referred to previously as corrugation ridges, have been interpreted as the product of tidal action that moves ice regularly up and down on a sedimentary seafloor (19). The ice can be in the form of iceberg keels, sub-ice shelf keels or a wider grounding line (Supplementary Text; Table S1). Where corrugation ridges are located within iceberg ploughmarks, they are likely to have been produced by the tidal motion of iceberg keels impinging on the seafloor (17). Corrugation ridges are also present within scours that are interpreted to have been produced by the forward ploughing of ice keels close to the grounding line (18). Where these ridges, or 'rungs', are more laterally extensive, as we observe over several kilometers on the Larsen shelf, and where they overprint MSGLs on the surface of GZWs (Fig. 2a), they likely form through regular vertical motion of an ice-sheet

110 grounding line that leads to the squeezing up of deforming soft sediment as small ridges on each falling tide (18). Indeed, it has been observed that short-lived perturbations in upstream longitudinal stress and ice flow, associated with tidal-induced flexure at the grounding zone, can cause small changes in the surface of the Antarctic Ice Sheet even tens of kilometers inland of the grounding line $(20,21)$. By contrast, recessional moraine ridges, which are

115 typically larger and less regularly spaced than the 'rungs' reported here (Table S1;

Supplementary Text), have been described from the Ross and Amundsen seas and are thought to form by short-lived readvances of the grounding line during overall retreat (22-24). In Svalbard fjords, such ridges form during small winter readvances of tidewater glacier termini during regional glacier recession $(25,26)$.

120 Given their presence overprinting MSGLs on GZW surfaces, and continuity over at least 5 $\mathrm{km}$, the rungs of our 'ladder and rung topography' are interpreted to form by grounding-line sediment squeezing in successive tidal cycles (Figs. 2, 3). Grounding-line retreat is necessary 
in order to preserve individual rungs produced as the ice presses into the underlying soft sediment on each falling tide; otherwise the delicate rung would be deformed or partially eroded during the next tidal cycle. The individual rungs are generally well-developed and simple in morphology, with little evidence of subsequent disturbance (Figs. 2, 3). We provide a schematic model of the formation and preservation of 'ladder and rung topography' at the retreating grounding line of an ice shelf (Fig. 4). Although we favour an interpretation in which rung formation occurs at the grounding-line, it is possible that these features were produced subglacially, contemporaneous with the MSGLs. Subglacial processes for the formation of subdued transverse ridges could include sediment squeezing into basal crevasses as the ice moves forward, and/or water flow over sediment in the depressions between the MSGLs (18).

Our interpretation of 'ladder and rung topography' as a product of tidally induced

135 grounding-line migration allows the past rate of deglacial retreat to be calculated over days to weeks. This is only possible due to the sub-meter resolution of our AUV-derived multibeam imagery (Figs. 2, 3). In the absence of systematic tidal-gauge observations, a numerical model of Weddell Sea tides by Padman et al. (27) predicts semi-diurnal tidal heights $<1.5 \mathrm{~m}$ for the Larsen area today; peak-to-peak ranges can exceed $3 \mathrm{~m}$ in some places, a value that is

140 likely to double at spring tides. During ship operations adjacent to Larsen C Ice Shelf in January 2019, we confirmed a strong coherency between the predictions of Padman's tidal model and our on-board observations. Although the configuration of the Weddell Sea during deglaciation will differ in detail from today due to isostatic rebound and the presence of residual inner-shelf ice, gross basin-form will be largely similar.

145 The rate of deglacial grounding-line retreat is derived from the spacing between each rung. Such an implication would be valid whether the rungs were in fact produced along a whole section of the groundling line or by discrete ice-shelf keels impinging on the seafloor (18), 
although we favour the former mechanism for the Larsen shelf features given their considerable lateral continuity. Average rung spacing is between 20 and $25 \mathrm{~m}$ and the number of observed rungs in the imaged area of each GZW is between 28 and 90 (Table 1); there are likely to be many more rungs on the unimaged distal surfaces of the GZWs. Assuming formation during each semi-diurnal tidal cycle, this yields an average grounding-line retreat between 40 and $50 \mathrm{~m} /$ day over periods between 14 and 45 days. If extrapolated over the GZW surfaces landward of our imaged area, this gives grounding-line retreat of about 18 $\mathrm{km} / \mathrm{yr}$, which might conservatively be halved to about $10 \mathrm{~km}$ if we assume that winter sea-ice cover might curtail ice-shelf flexure associated with long-period swell waves for about half the year (28). This retreat rate of many kilometers per year is at least an order of magnitude higher than that observed between 1992 and 2011 at Pine Island Glacier (1.6 km/yr) (29), which was itself two orders of magnitude greater than the average retreat rate for the last 10,000 years (30). Short-lived phases of very rapid post-LGM retreat, of up to $100 \mathrm{~km} / \mathrm{yr}$, have also been simulated in numerical experiments by Jamieson et al. (31). The alternative model of rung formation, in which the rungs are produced subglacially (18), implies even higher rates of grounding-line retreat, as the ice would have to lift off from its bed nearinstantaneously in order to preserve the delicate rungs. continental shelf could have taken place in approximately one year. The multiple sets of GZWs suggest that periods of readvance and still-stand punctuated overall retreat, demonstrating the highly dynamic behaviour of the grounding line. Presumably, final rapid retreat would have exposed the distal sections of the GZW complex and continued through the remaining $30 \mathrm{~km}$ or so of Larsen Inlet, given the deepening water landward of our study area (Fig. 1a), and the increasing buoyancy and calving rate at the grounding line that would result. Thus, it appears that final deglacial retreat from the still-stand represented by the last 
of the 10-20 m thick GZWs was very rapid. This explains, too, why many streamlined glacial landforms, produced subglacially prior to deglaciation, are typically well-preserved and not overprinted by other landforms - retreat is sufficiently rapid that there is little deposition. Grounding-line retreat, as inferred here over each tidal cycle, is not necessarily accompanied by retreat of the ice-shelf frontal margin. For example, Pine Island Glacier underwent a sustained grounding-line retreat of $\sim 30 \mathrm{~km}$ between 1992 and $2011(3,4)$ but did not experience any significant change in its ice-shelf frontal position during that observational 180 period (32).

The wider significance of our high-resolution observations of a past ice-shelf GZW complex is to show using the geological record that very high rates of grounding-line retreat are possible, greater by an order of magnitude than those reported for ice shelves since satellite observations began. Thus, a grounding-line retreat of, for example, $10 \mathrm{~km} / \mathrm{yr}$ along a

$1855 \mathrm{~km}$ length of a $500 \mathrm{~m}$ thick ice stream would yield a total ice mass loss of $25 \mathrm{~km}^{3} / \mathrm{yr}(23$ $\mathrm{Gt} / \mathrm{yr}$ using an assumed ice density of $916.7 \mathrm{~kg} / \mathrm{m}^{3}$ ). A similar calculation extrapolated across a $30 \mathrm{~km}$-wide and $1 \mathrm{~km}$-thick grounding line, the typical width and thickness of most icestream centers in modern Pine Island Bay in West Antarctica, yields a total mass loss of 150 $\mathrm{km}^{3} / \mathrm{yr}(138 \mathrm{Gt} / \mathrm{yr})$. This value is 3-5 times greater than mean contemporary (1992-2017)

190 rates of mass loss integrated over Pine Island Glacier's entire drainage basin $\left(31 \mathrm{~km}^{3} / \mathrm{yr} ; 28.4\right.$ Gt/yr) and the combined Thwaites-Pope-Smith-Kohler Glacier drainage system $\left(50.3 \mathrm{~km}^{3} / \mathrm{yr}\right.$; 46.1 Gt/yr), respectively (33). This implies that the rapid retreat of even a single Antarctic outlet glacier could, therefore, increase substantially the short-term mass-loss from the ice sheet. This is without taking account of residual ice-dynamic effects associated with ice-shelf loss (34); the removal of this buttressing effect provides an additional mechanism for substantial increases in ice discharge to the ocean from interior drainage basins $(1,2,35)$. In addition, once retreat at this pace has begun, the self-stabilizing process of continuing 
subglacial sediment delivery to the grounding line to offset deglacial ice-shelf thinning and/or sea-level rise $(36,37)$ ceases to be important given the very short time, perhaps only a year or two, for sediment build-up.

\section{References and Notes:}

(1) T. K. Dupont, R. B. Alley, Assessment of the importance of ice-shelf buttressing to icesheet flow. Geophysical Research Letters 32, doi:10.1029/2004GL022024 (2005).

(2) D. Goldberg, D. M. Holland, C. Schoof, Grounding line movement and ice shelf buttressing in marine ice sheets. Journal of Geophysical Research: Earth Surface 14, doi:10.1029/2008JF001227 (2009).

(3) J. W. Park, N. Gourmelen, A. Shepherd, S. W. Kim, D. G. Vaughan, D. J. Wingham, Sustained retreat of the Pine Island Glacier. Geophysical Research Letters 40, 2137-2142 $210 \quad$ (2013).

(4) E. Rignot, J. Mouginot, B. Scheuchl, MEaSUREs Antarctic Grounding Line from Differential Satellite Radar Interferometry, Version 2, digital media, NASA National Snow and Ice Data Center Distributed Active Archive Center, Boulder, Colorado, USA, doi:10.5067/IKBWW4RYHF1Q (2016).

215 (5) C. L. Batchelor, J. A. Dowdeswell, Ice-sheet grounding-zone wedges (GZWs) on highlatitude continental margins. Marine Geology 363, 65-92 (2015).

(6) R. B. Alley, D. D. Blackenship, S. T. Rooney, C. R. Bentley, Sedimentation beneath ice shelves - the view from Ice Stream B. Marine Geology 85, 101-120 (1989).

(7) J. A. Dowdeswell, E. M. G. Fugelli, The seismic architecture and geometry of groundingzone wedges formed at the marine margins of past ice sheets. Bulletin of the Geological Society of America 124, 1750-1761 (2012). 
(8) K. Christianson, R. W. Jacobel, H. J. Horgan, R. B. Alley, S. Anandakrishnan, D. M. Holland, K. J. DallaSanta, Basal conditions at the grounding zone of Whillans Ice Stream, west Antarctica, from ice penetrating radar. Journal of Geophysical Research 121, 19541983 (2016).

(9) J. A. Dowdeswell, M. Canals, M. Jakobsson, B. J. Todd, E. K. Dowdeswell, K. A. Hogan, "The variety and distribution of submarine glacial landforms and implications for icesheet reconstruction" in Atlas of Submarine Glacial Landforms: Modern, Quaternary and Ancient, J. A. Dowdeswell, M. Canals, M. Jakobsson, B. J. Todd, E. K. Dowdeswell, K. A. Hogan, Eds. (Springer, 2016), Geological Society, London, Memoirs, vol. 46, 519522.

(10) J. A. Dowdeswell, J. Evans, R. Mugford, G. Griffiths, S. McPhail, N. Millard, P. Stevenson, M. A., Brandon, C. Banks, K. J. Heywood, M. R. Price, P. A. Dodd, A. Jenkins, K. W. Nicholls, D. Hayes, E. P. Abrahamsen, P. Tyler, B. Bett, D. Jones, P. Wadhams, J. P. Wilkinson, K. Stansfield, S. Ackley, Autonomous underwater vehicles (AUVs) and investigations of the ice-ocean interface in Antarctic and Arctic waters. Journal of Glaciology 54, 661-672 (2008).

(11) J. Evans, C. J. Pudsey, C. Ó Cofaigh, P. W. Morris, E. W. Domack, Late Quaternary glacial history, dynamics and sedimentation of the eastern margin of the Antarctic Peninsula Ice Sheet. Quaternary Science Reviews 24, 741-774 (2005).

(12) S. Brachfeld, E. W. Domack, C. Kissel, C. Laj, A. Leventer, S. Ishman, R. Gilbert, A. Camerlenghi, L. B. Eglinton, Holocene history of the Larsen-A Ice Shelf constrained by geomagnetic paleointensity dating. Geology 31, 749-752 (2003).

(13) C. Ó Cofaigh, B. J. Davies, S. J. Livingstone, J. A. Smith, J. S. Johnson, E. P. Hocking, D. A. Hodgson, J. B. Anderson, M. J. Bentley, M. Canals, E. Domack, J. A. Dowdeswell, J. Evans, N. F. Glasser, C.-D, Hillenbrand, R. D. Larter, S. J. Roberts, A. R. Simms, 
Reconstruction of ice-sheet changes in the Antarctic Peninsula since the last glacial maximum. Quaternary Science Reviews 100, 87-110 (2014).

(14) C. J. Pudsey, J. W. Murray, P. Appleby, J. Evans, Ice shelf history from petrographic and foraminiferal evidence, northeast Antarctic Peninsula. Quaternary Science Reviews 25, 2357-2379 (2006).

(15) C. D. Clark, Mega-scale glacial lineations and cross-cutting ice-flow landforms. Earth Surface Processes and Landforms 18, 1-29 (1993).

(16) E. C. King, R. C. A. Hindmarsh, C. R. Stokes, Formation of mega-scale glacial lineations observed beneath a West Antarctic ice stream. Nature Geoscience 2, 585-588 (2009).

(17) M. Jakobsson, J. B. Anderson, F. Nitsche, J. A. Dowdeswell, R. Gyllencreutz, N. Kirchner, R. Mohammad, M. O’Regan, R. B. Alley, S. Anandakrishnan, B. Eriksson, A. Kirshner, R. Fernandez, T. Stolldorf, R. Minzoni, W. Majewski, Geological record of ice shelf break-up and grounding line retreat, Pine Island Bay, West Antarctica. Geology 39, 691-694 (2011).

(18) A. G. C. Graham, P. Dutrieux, D. G. Vaughan, F. O. Nitsche, R. Gyllencreutz, S. L. Greenwood, R. D. Larter, A. Jenkins, Seabed corrugations beneath an Antarctic ice shelf revealed by autonomous underwater vehicle survey: origin and implications for the history of Pine Island Glacier. Journal of Geophysical Research 118, 1356-1366 (2013).

265 (19) J. A. Smith, A. G. C. Graham, A. L. Post, C.-D. Hillenbrand, P. J. Bart, R. D. Powell, The marine geological imprint of Antarctic ice shelves. Nature Communications 10, 5635 (2019).

(20) R. A. Bindschadler, M. A. King, R. B. Alley, S. Anandakrishnan, L. Padman, Tidally controlled stick-slip discharge of a West Antarctic ice stream. Science 301, 1087-1089 (2003). 
(21) B. M. Minchew, M. Simons, B. Riel, P. Milillo, Tidally induced variations in vertical and horizontal motion on Rutford Ice Stream, West Antarctica, inferred from remotely sensed observations. Journal of Geophysical Research 122, 167-190 (2017).

(22) A. R. W. Halberstadt, L. M. Simkins, S. L. Greenwood, J. B. Anderson, Past ice-sheet behaviour: retreat scenarios and changing controls in the Ross Sea, Antarctica. The Cryosphere 10, 1003-1020 (2016).

(23) J. P. Klages, G. Kuhn, C.-D. Hillenbrand, A. G. C. Graham, J. A. Smith, R. D. Larter, K. Gohl, "A glacial landform assemblage from an inter-ice stream setting in the eastern Amundsen Sea Embayment, West Antarctica" in Atlas of Submarine Glacial Landforms: Modern, Quaternary and Ancient, J. A. Dowdeswell, M. Canals, M. Jakobsson, B. J. Todd, E. K. Dowdeswell, K. A. Hogan, Eds. (Springer, 2016), Geological Society, London, Memoirs, vol. 46, 349-352.

(24) L. M. Simkins, J. B. Anderson, S. L. Greenwood, H. M. Gonnermann, L. O. Prothro, A. R. W. Halberstadt, L. A. Stearns, D. Pollard, R. M. DeConto, Anatomy of a meltwater 285 drainage system beneath the ancestral East Antarctic ice sheet. Nature Geoscience 10, 691-697 (2017).

(25) G. S. Boulton, Push-moraines and glacier-contact fans in marine and terrestrial environments. Sedimentology 33, 677-698 (1986).

(26) D. Ottesen, J. A. Dowdeswell, Assemblages of submarine landforms produced by tidewater glaciers in Svalbard. Journal of Geophysical Research 111, 1-16 (2006).

(27) L. Padman, M. R. Siegfried, H. A. Fricker, Ocean tide influences on the Antarctic and Greenland ice sheets. Reviews of Geophysics 56, 142-184 (2018).

(28) R. A. Massom, T. A. Scambos, L. G. Bennetts, P. Reid, V. A. Squire, S. E. Stammerjohn, Antarctic ice shelf disintegration triggered by sea ice loss and ocean swell. Nature 558, 383-389 (2018). 
(29) E. Rignot, J. Mouginot, M. Morlighem, H. Seroussi, B. Scheuchl, Widespread, rapid grounding line retreat of Pine Island, Thwaites, Smith, and Kohler glaciers, West Antarctica, from 1992 to 2011. Geophysical Research Letters 421, 3502-3509 (2014).

(30) C.-D. Hillenbrand, G. Kuhn, J. A. Smith, K. Gohl, A. G. C. Graham, R. D. Larter, J. P. Klages, R. Downey, S. G. Moreton, M. Forwick, D. G. Vaughan, Grounding-line retreat of the West Antarctic Ice Sheet from inner Pine Island Bay. Geology 41, 35-38 (2013).

(31) S. S. R. Jamieson, A. Vieli, S. J. Livingstone, C. Ó Cofaigh, C. Stokes, C.-D. Hillenbrand, J. A. Dowdeswell, Ice-stream stability on a reverse bed slope. Nature Geoscience 5, 799-802 (2012).

305 (32) H. D. Pritchard, S. R. M. Ligtenberg, H. A. Fricker, D. G. Vaughan, M. R. van den Broeke, L. Padman, Antarctic ice-sheet loss driven by basal melting of ice shelves. Nature 484, 502-505 (2012).

(33) A. Shepherd, L. Gilbert, A. S. Muir, H. Konrad, M. McMillan, T. Slater, K. H. Briggs, A. V. Sundal, A. E. Hogg, M. E. Engdahl, Trends in Antarctic Ice Sheet Elevation and Mass. Geophysical Research Letters 46, 8174-8183 (2019).

(34) J. Mouginot, E. Rignot, B. Scheuchl, Sustained increase in ice discharge from the Amundsen Sea embayment, West Antarctica. Geophysical Research Letters 41, 1576$1584(2014)$.

(35) T. A. Scambos, J. A. Bohlander, C. A. Shuman, P. Skvarca, Glacier acceleration and thinning after ice shelf collapse in the Larsen B embayment, Antarctica. Geophysical Research Letters 31, doi:10.1029/2004/GL020670 (2004).

(36) R. B. Alley, S. Anandakrishnan, T. K. Dupont, B. R. Parizek, D. Pollard, Effect of sedimentation on ice-sheet grounding-line stability. Science 315, 1838-1841 (2007).

(37) S. Anandakrishnan, G. A. Catania, R. B. Alley, H. J. Horgan, Discovery of till deposition at the grounding line of Whillans Ice Stream. Science 315, 1835-1838 (2007). 
(38) J. E. Arndt, H. W. Schenke, M. Jakobsson, F. O. Nitsche, G. Buys, B. Goleby, M. Rebesco, F. Bohoyo, J. Hong, J. Black, R. Greku, G. Udintsev, F. Barrios, W. ReynosoPeralta, M. Taisei, R. Wigley, The International Bathymetric Chart of the Southern Ocean (IBCSO) Version 1.0 - A new bathymetric compilation covering circum-Antarctic waters. Geophysical Research Letters 40, 3111-3117 (2013).

(39) A. J. Cook, D. G. Vaughan, A. J. Luckman, T. Murray, A new Antarctic Peninsula glacier basin inventory and observed area changes since the 1940s. Antarctic Science 26, 614-624 (2014).

(40) K. Kim, K. C. Jezek, H. Liu, Orthorectified image mosaic of Antarctica from 1963 Argon satellite photography: image processing and glaciological implications. International Journal of Remote Sensing 28, 5357-5373 (2007).

(41) J. Evans, K. A. Hogan, "Grounding-zone wedges on the northern Larsen shelf, Antarctic Peninsula" in Atlas of Submarine Glacial Landforms: Modern, Quaternary and Ancient, J. A. Dowdeswell, M. Canals, M. Jakobsson, B. J. Todd, E. K. Dowdeswell, K. A. Hogan, Eds. (Springer, 2016), Geological Society, London, Memoirs, vol. 46, 237-238.

(42) C. Lavoie, E. W. Domack, E. C. Pettit, T. A. Scambos, R. D. Larter, H.-W. Schenke, K. C. Yoo, J. Gutt, J. Wellner, M. Canals, J. B. Anderson, D. Amblas, Configuration of the Northern Antarctic Peninsula Ice Sheet at LGM based on a new synthesis of seabed imagery. The Cryosphere 9, 613-629 (2015).

340 (43) J. M. Campo, J. S. Wellner, E. Domack, C. Lavoie, K.-C. Yoo, Glacial geomorphology of the northwestern Weddell Sea, eastern Antarctic Peninsula continental shelf: shifting ice flow patterns during deglaciation. Geomorphology 280, 89-107 (2017).

(44) P. W. Barnes, R. Lien, Icebergs rework shelf sediments to $500 \mathrm{~m}$ off Antarctica. Geology 16, 1130-1133 (1988). 
345 (45) R. Lien, A. Solheim, A. Elverhøi, K. Rokoengen, Iceberg scouring and sea bed morphology on the eastern Weddell Sea shelf, Antarctica. Polar Research 7, 43-57 (1989).

(46) J. P. Klages, G. Kuhn, A. G. C. Graham, C.-D. Hillenbrand, J. A. Smith, F. O. Nitsche, R. D. Larter, K. Gohl, Palaeo-ice stream pathways and retreat style in the easternmost Amundsen Sea Embayment, West Antarctica, revealed by combined multibeam bathymetric and seismic data. Geomorphology 245, 207-222 (2015).

(47) M. Jakobsson, J. B. Anderson, "Corrugation ridges in the Pine Island Bay glacier trough, West Antarctica" in Atlas of Submarine Glacial Landforms: Modern, Quaternary and Ancient, J. A. Dowdeswell, M. Canals, M. Jakobsson, B. J. Todd, E. K. Dowdeswell, K. A. Hogan, Eds. (Springer, 2016), Geological Society, London, Memoirs, vol. 46, 265266.

(48) K. Andreassen, M. C. M. Winsborrow, L. R. Bjarnadóttir, D. C. Rüther, Ice stream retreat dynamics inferred from an assemblage of landforms in the northern Barents Sea. Quaternary Science Reviews 92, 246-257 (2014).

360 (49) J. A. Dowdeswell, K. A. Hogan, "Huge iceberg ploughmarks and associated corrugation ridges on the northern Svalbard shelf" in Atlas of Submarine Glacial Landforms: Modern, Quaternary and Ancient, J. A. Dowdeswell, M. Canals, M. Jakobsson, B. J. Todd, E. K. Dowdeswell, K. A. Hogan, Eds. (Springer, 2016), Geological Society, London, Memoirs, vol. 46, 269-270.

365 (50) S. S. Shipp, J. S. Wellner, J. B. Anderson, "Retreat signature of a polar ice stream: subglacial geomorphic features and sediments from the Ross Sea, Antarctica” in GlacierInfluenced Sedimentation on High-Latitude Continental Margins, J. A. Dowdeswell, C. Ó Cofaigh, Eds. (Springer, 2002), Geological Society, London, Special Publications, vol. 203, 277-304. 
370 (51) P. E. O’Brien, L. De Santis, P. T. Harris, E. Domack, P. G. Quilty, Ice shelf grounding zone features of western Prydz Bay, Antarctica: sedimentary processes from seismic and sidescan images. Antarctic Science 11, 78-91 (1999).

(52) M. Lindén, P. Möller, Marginal formation of De Geer moraines and their implications to the dynamics of grounding-line recession. Journal of Quaternary Science 20, 113-133

$375 \quad$ (2005).

(53) D. J. Burton, J. A. Dowdeswell, K. A. Hogan, R. Noormets, "Little Ice Age terminal and retreat moraines in Kollerfjorden, NW Spitsbergen" in Atlas of Submarine Glacial Landforms: Modern, Quaternary and Ancient, J. A. Dowdeswell, M. Canals, M.

Jakobsson, B. J. Todd, E. K. Dowdeswell, K. A. Hogan, Eds. (Springer, 2016), Geological 380 Society, London, Memoirs, vol. 46, 71-72.

(54) J. P. Klages, G. Kuhn, C.-D. Hillenbrand, A. G. C. Graham, J. A. Smith, R. D. Larter, K. Gohl, First geomorphological record and glacial history of an inter-ice stream ridge on the West Antarctic continental shelf. Quaternary Science Reviews 61, 47-61 (2013).

(55) L. M. Simkins, S. L. Greenwood, J. B. Anderson, Diagnosing ice sheet grounding line 385 stability from landform morphology. The Cryosphere 12, 2707-2726 (2018).

(56) C. L. Batchelor, J. A. Dowdeswell, K. A. Hogan, R. D. Larter, E. Parsons, O. West, Processes and patterns of glacier-influenced sedimentation and recent tidewater glacier dynamics in Darbel Bay, western Antarctic Peninsula. Antarctic Science 31, 218-227 (2019).

390 (57) J. B. Anderson, Antarctic Marine Geology (Cambridge University Press, 1999).

Acknowledgments: AUV deployments were from the South African icebreaking research vessel S.A. Agulhas II, and we thank the Captain, Ice Pilot, Officers and Crew for their support of our work; Funding: This research was funded by the Flotilla 

associated technical support was provided by Ocean Infinity and Deep Ocean Search. During this work, C.L.B. was in receipt of a grant from the Norwegian VISTA programme; Author contributions: All authors took part in the acquisition and interpretation of the marine-geophysical data included in this paper. JAD wrote the paper and each co-author contributed comments and suggestions during a number of iterations of the text and figures; Competing interests: Authors declare no competing interests; and Data and materials availability: All data are shown in the main text or the Supplementary Materials.

\section{List of Supplementary Materials:}

Materials and Methods

Supplementary Text

Figure S1

Table S1

$410 \quad$ References (41-57)

Fig. 1. Map of the study area. (A) Map showing the location of the surveyed grounding-zone wedge complex in Larsen Inlet (red box). Black lines are GZW crests. White arrows show the former ice-flow direction. Red circles are locations of sediment cores KC023, VC247 and

415 VC318. Background land area is from a Sentinel-2b Level-1C Top of Atmosphere reflectance image acquired on 5 December 2018. Background bathymetry is from the International Bathymetric Chart of the Southern Ocean (IBCSO) (38). BDE Trough = Bombardier, Dinsmoor and Edgemoor Trough. 1986, 1989 and 1995 ice-shelf frontal positions are from Cook et al. (39), and the 1963 ice-shelf front position was ascertained from declassified 
420 Argon satellite imagery (40). Inset shows the location of the study area (red box) on the Antarctic Peninsula (AP). Dashed grey line is present-day shelf break. LC = Larsen C Ice Shelf. (B) Bathymetric image of a GZW complex beyond Larsen Inlet, acquired from RRS James Clark Ross in 2002 using a Kongsberg EM120 multibeam echo-sounder with a frequency of $12 \mathrm{kHz}$. Grid-cell size $50 \mathrm{~m}$. The image is modified from Evans et al. (11). 425 Black arrows show GZW crests.

Fig. 2. Geophysical data showing a GZW complex in Larsen Inlet, acquired from an AUV. (A) Bathymetric data of the GZW complex, derived from an AUV-deployed multibeam echosounder. Grid cell-size is $1 \mathrm{~m}$. Location is in Fig. 1a. (B) Interpretation of individual GZWs within the grounding-zone complex. Inset is a schematic diagram showing GZW stratigraphy as derived from multibeam echo-sounder data and sub-bottom profiles. GZWs a and 2-5 rest on an older surface (labelled 1). GZW a overlies surface 1 and is beneath GZW 5, but its stratigraphic position relative to GZWs 2-4 is unknown. (C) and (D) Sub-bottom profiles along the GZWs, showing the GZW stratigraphy and a thin $(\sim 0.7 \mathrm{~m})$ uppermost draping unit (pink fill). (E) and (F) Detail of debris-flow lobes on the seaward flank of the GZWs.

Fig. 3. Detail of 'ladder and rung topography'. (A) The mapped distribution of 'rungs' or transverse-to-flow ridges on GZW surfaces. (B) and (C) Details of transverse-to-flow ridges on GZW surfaces. (D) and (E) Profiles across the 'rungs' shown in (B) and (C).

Fig. 4. Schematic model (not to scale) of the hypothesised formation of 'rungs' or transverseto-flow ridges on the surface of a GZW. When a glacier transitions into a floating ice shelf, delicate transverse-to-flow ridges can form by tidally influenced 'sit-downs' of the grounding line. The ridges are formed at low tide by ice squeezing and pushing of sediments at the 
grounding line. The plan-view shape of the ridges reflects lateral variations in the shape of the grounding line. Series of parallel to sub-parallel ridges are formed when there is continuous grounding-line retreat. Because the ice is actively flowing during grounding-line retreat, as indicated by the presence of mega-scale glacial lineations (MSGLs), the parallel to sub-parallel nature of the rungs/ridges suggests that the shape of the ice-sheet base remained relatively constant in the ice-flow direction.

\begin{tabular}{|c|c|c|c|c|c|c|c|}
\hline $\begin{array}{c}\text { GZW } \\
\text { surface }\end{array}$ & $\begin{array}{c}\text { GZW } \\
\text { max. } \\
\text { thickness } \\
(\mathbf{m})\end{array}$ & $\begin{array}{c}\text { GZW } \\
\text { planar } \\
\text { area } \\
\left(\mathbf{k m}^{2}\right)\end{array}$ & $\begin{array}{c}\text { Number } \\
\text { of ridges }\end{array}$ & $\begin{array}{c}\text { Ridge } \\
\text { height } \\
(\mathbf{m})\end{array}$ & $\begin{array}{c}\text { Average } \\
\text { ridge } \\
\text { spacing } \\
(\mathbf{m})\end{array}$ & $\begin{array}{c}\text { Average } \\
\text { daily } \\
\text { retreat } \\
(\mathbf{m})\end{array}$ & $\begin{array}{c}\text { Retreat } \\
\text { duration } \\
\text { (days) }\end{array}$ \\
\hline $\begin{array}{c}\mathbf{1} \\
\text { (several) }\end{array}$ & $/$ & 3.1 & 71 & $0.1-0.4$ & 20 & 40 & 35 \\
\hline $\mathbf{a}$ & 3 & 0.4 & 33 & $0.2-0.3$ & 24 & 48 & 16 \\
\hline $\mathbf{2}$ & $/$ & 0.3 & 28 & $0.2-0.6$ & 25 & 50 & 14 \\
\hline $\mathbf{3}$ & 16 & 1.4 & 44 & $0.3-1.0$ & 20 & 40 & 22 \\
\hline $\mathbf{4}$ & 15 & 2.3 & 90 & $0.5-1.5$ & 21 & 42 & 45 \\
\hline $\mathbf{5}$ & 9 & 1.0 & 40 & $0.2-0.4$ & 20 & 40 & 20 \\
\hline
\end{tabular}

Table 1. Morphological characteristics of 'rungs' or transverse-to-flow ridges on GZW surfaces in the study area. GZW thickness is maximum thickness derived from sub-bottom profiles. GZW area is only given for those parts of the GZWs that were surveyed from the AUV (Fig. 2a); the GZWs most probably extend beyond the study area. Average daily retreat and retreat duration values are calculated assuming that the ridges were produced by tidally influenced 'sit-downs' of the grounding line (i.e. two rungs/ridges produced per day). 
465

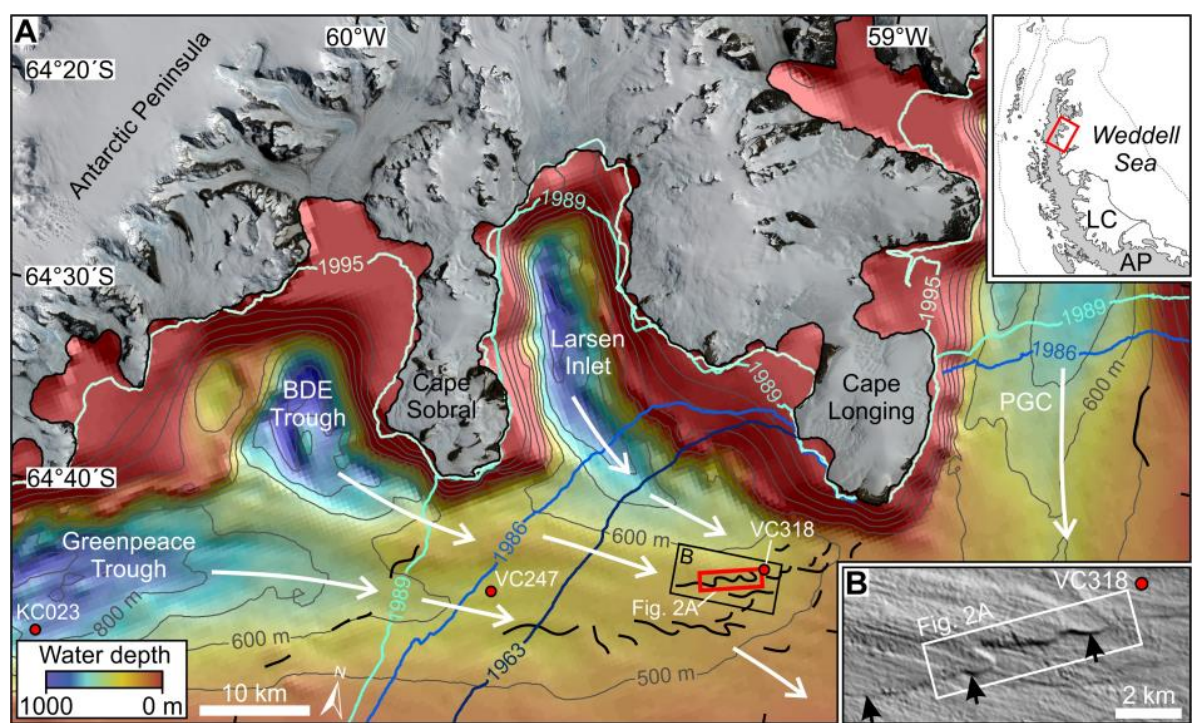

Figure 1

475

480 
490

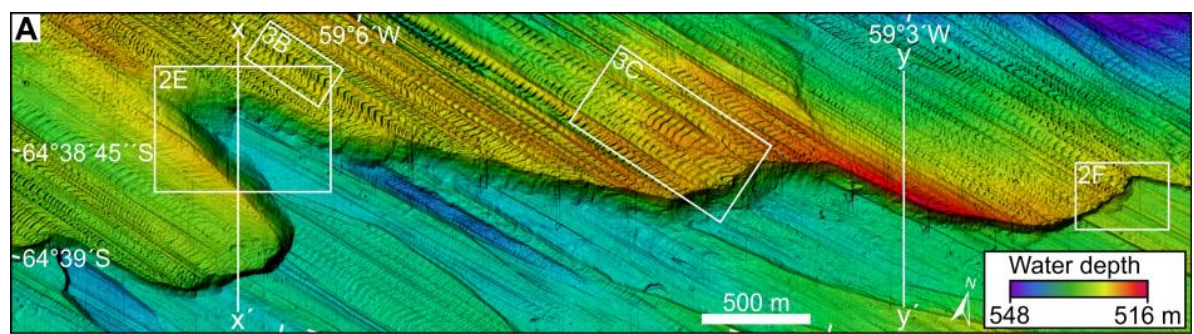

495
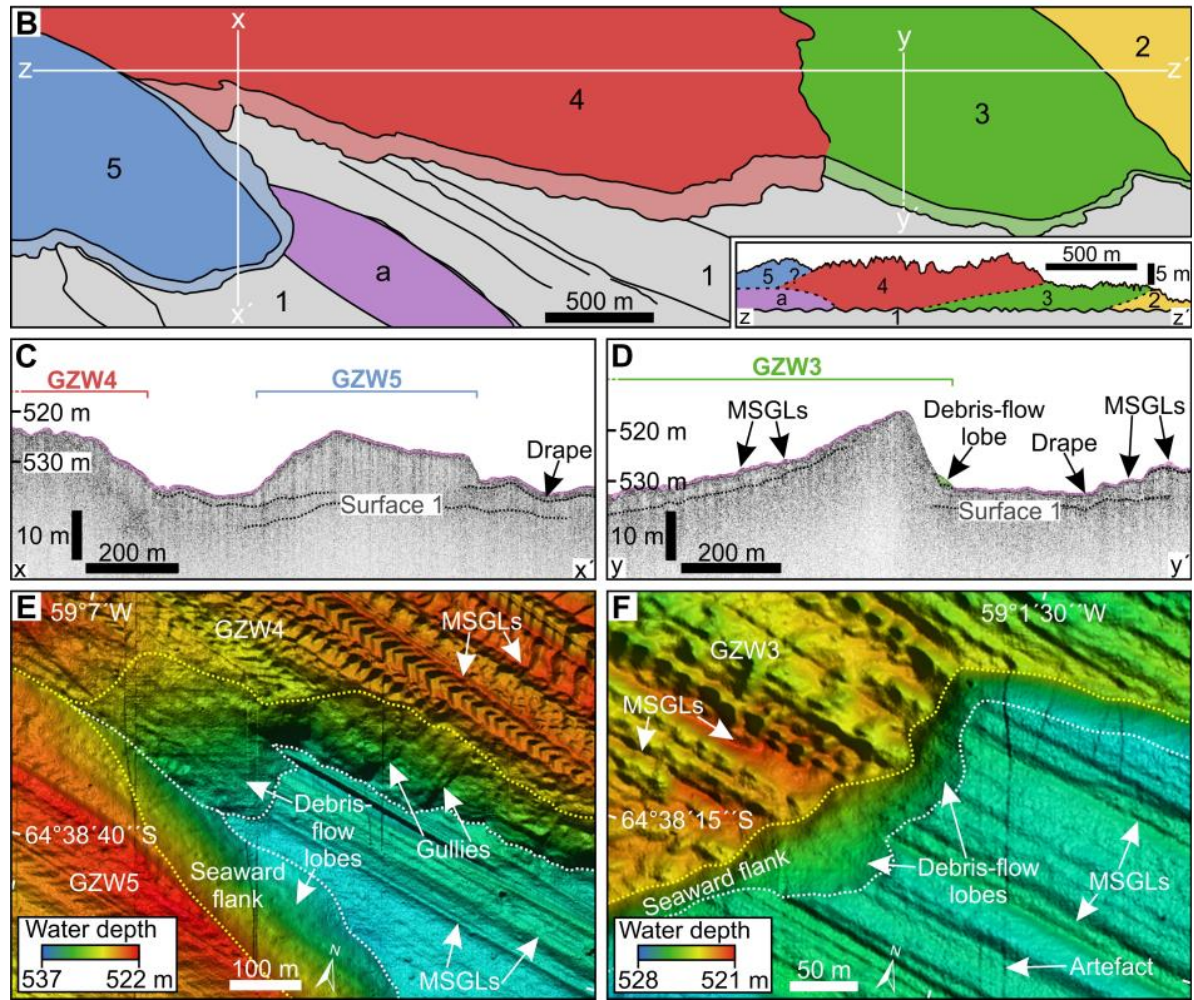

Figure 2 


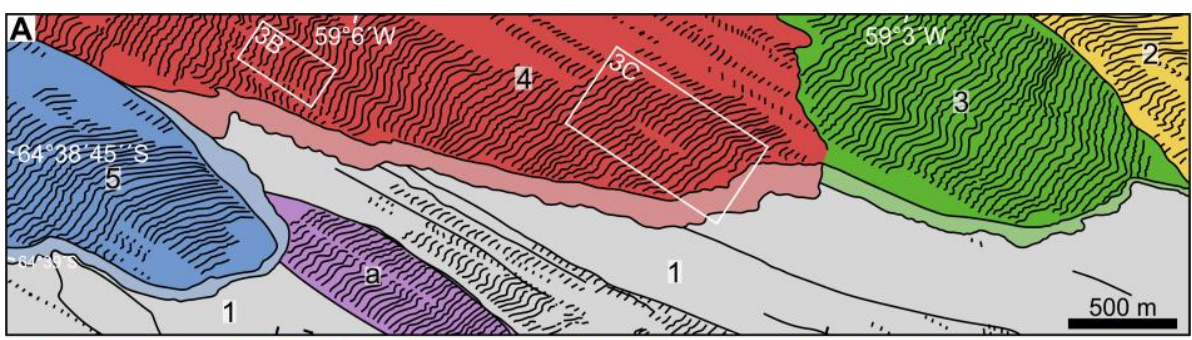

520
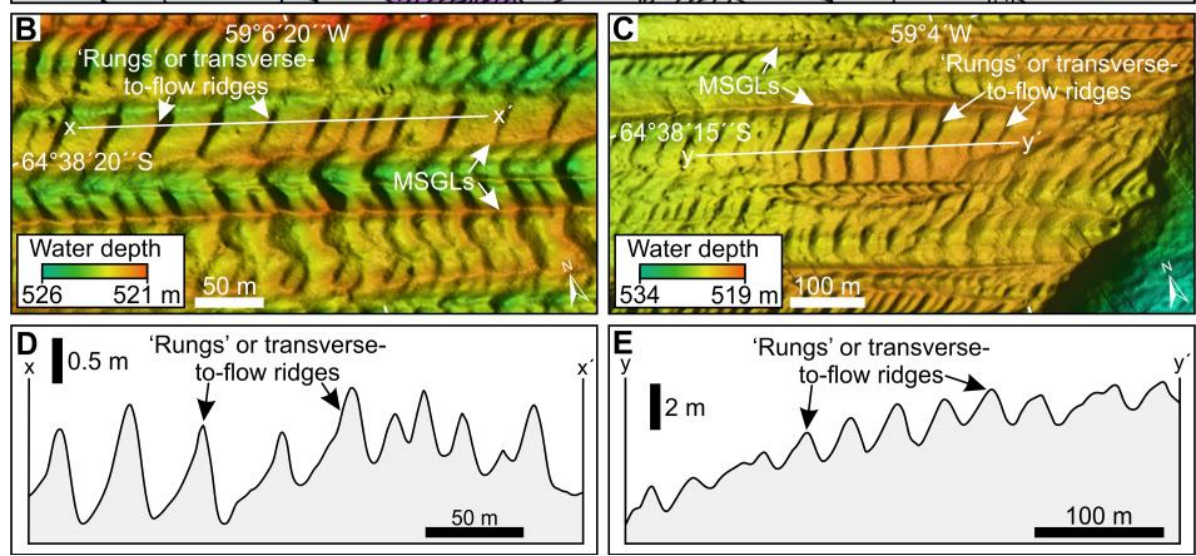

Figure 3 


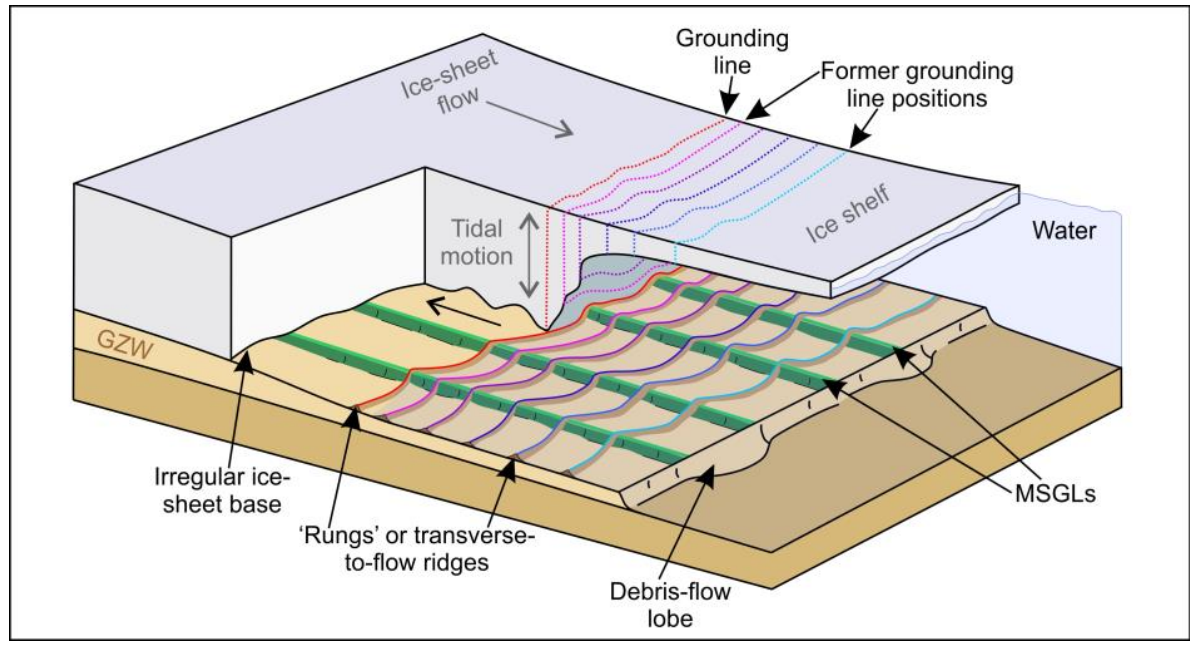

Figure 4 


\section{Science MIAAAS}

\section{Supplementary Materials for}

Delicate seafloor landforms reveal past Antarctic grounding-line retreat of kilometers per year

J.A. Dowdeswell, C.L. Batchelor, A. Montelli, D. Ottesen, F.D.W. Christie, E.K. Dowdeswell, J. Evans

Correspondence to: jd16@cam.ac.uk

\section{This PDF file includes:}

Materials and Methods

Supplementary Text

Fig. S1

Table S1

References (41-57) 


\section{Materials and Methods}

Multibeam swath-bathymetric data of the seafloor were acquired during a precisely geolocated 12-hour dive of a Kongsberg Maritime Hugin 6000 AUV to image the complex of GZWs on the Larsen continental shelf in great detail. The AUV was fitted with an EM2040 multibeam echo-sounder with 400 individual beams operated at $400 \mathrm{kHz}$ and an EdgeTech 216 sub-bottom profiler operating at $11 \mathrm{kHz}$ to provide shallow acoustic stratigraphy. The AUV flew at a speed of 3.6 knots at $70 \mathrm{~m}$ above the seafloor in bottom-tracking mode, giving a swath-width of $400 \mathrm{~m}$ for the multibeam echo-sounder. An area of almost $9 \mathrm{~km}^{2}$ was imaged at a horizontal resolution of about $0.5 \mathrm{~m}$ using the multibeam system, and 64 line-km of sub-bottom profiler data were acquired on 32 legs to image the GZWs (Fig. S1).

Previous observations of the Larsen Inlet area from conventional hull-mounted multibeam echo-sounders had enabled the mapping of the GZW complex on the shelf beyond Larsen Inlet at a horizontal resolution of a few tens of meters (Fig. 1b) (11, 41-43). Knowledge of the location and general shape of the GZWs allowed us to construct the detailed grid survey in Figure S1 used in our high-resolution AUV-derived geophysical survey of the GZW complex. 


\section{Supplementary Text}

Fine-scale ridges in the geological record

The term 'corrugation ridges' has been used previously to encompass a variety of fine-scale, transverse-to-flow ridges that are preserved on glaciated continental shelves. We interpret corrugation ridges as being produced by the tidally influenced grounding and ungrounding of ice into seafloor sediments. The ridges appear to form in three different glaciological settings: by icebergs, by sub-ice shelf keels, and at the grounding line (see references in Table S1).

\section{Corrugation ridges}

Many of the fine-scale ridges that have been described previously as corrugation ridges on Antarctic continental shelves have been identified within linear to curvilinear depressions that are interpreted as iceberg ploughmarks $(17,19,22,44-47)$. In these cases, fine-scale ridges up to $3 \mathrm{~m}$ high have been suggested to form as icebergs move vertically with tides, causing their keels to contact and press into the seafloor intermittently. The parallel conformity of the ploughmarks and the regular spacing of the corrugation ridges have been explained by the icebergs being trapped within a frozen mélange of sea ice and small bergs $(18,19)$. Similar features have been reported from Arctic continental shelves $(48,49)$.

Corrugation ridges have also been identified within linear to curvilinear depressions that are interpreted to have been produced by the forward ploughing of sub-ice shelf keels close to the grounding line $(18,19,22,46)$. Sub-ice shelf keel scours can be distinguished from subglacially produced mega-scale glacial lineations (MSGLs) by their erosional form and lower parallel conformity. In addition, sub-ice shelf keel scours are often associated with terminal mounds that are formed by the pushing of sediment in front of the sub-ice shelf keel (19).

The 'ladder and rung topography' that we report and illustrate from Larsen Inlet (Figs. 2 and 3) is interpreted to have been produced by the squeezing up of soft sediment during the rise and fall of the ice-sheet grounding line during successive tidal cycles. These fine-scale ridges differ from those that are interpreted to have been produced by the tidal motion of icebergs or sub-ice shelf keels (Table S1). Most notably, the ridges in Larsen Inlet are not confined within linear to curvilinear grooves that are interpreted as iceberg ploughmarks or sub-ice shelf keel scours. Instead, they are laterally continuous over a broad $(c .5 \mathrm{~km})$ region of the seafloor (Fig. 2a) where they can be traced overprinting elongate linear ridges (Fig. 3b and c) on the lowgradient upper surface of GZWs. The linear ridges are interpreted as MSGLs because of their narrow spacing (50-200 m) and high parallel conformity (Fig. 2a). Comparison of geomorphological characteristics suggests that the 'rungs' in Larsen Inlet are generally slightly more subdued and more closely spaced than corrugation ridges that have been identified within iceberg ploughmarks or sub-ice shelf scours in Antarctica (Table S1). The cross-sectional geometry of the 'rungs', which is often asymmetric with a steeper ice-distal side (Fig. 3b and c), is interpreted to result from the squeezing of sediment into accommodation space immediately seaward of the grounding line (Fig. 4). This asymmetry is difficult to reconcile with ridge formation through the periodic grounding of sub-ice shelf keels.

We propose that the fine-scale features reported from the Ross Sea (50) and Prydz Bay, East Antarctica (51), may be similar to the 'ladder and rung topography' that we present from Larsen Inlet, which we interpret to have been formed by tidal motion of the grounding line (Table S1). The 'corrugation moraines' that have been described by Shipp et al. (50) in the Ross Sea, which are 1-2 m high and spaced 40-100 m apart, occur on the low-gradient upper surface of GZWs 
and are associated with MSGLs. Similarly, ridges up to $1 \mathrm{~m}$ high and spaced around $50 \mathrm{~m}$ apart are described from Prydz Bay, East Antarctica, where they are associated with the upper surface of GZWs and have a slightly convex form between MSGLs (51).

The fine-scale ridges that we present from Larsen Inlet also appear similar to the seafloor corrugations reported from beneath Pine Island Glacier ice shelf by Graham et al. (18), which were interpreted to have been formed by tidal motion during the forward ploughing of sub-ice shelf keels. The ridges beneath Pine Island Glacier ice shelf have similar dimensions (heights of 0.1-1 m) and regular spacing (roughly 50-80 m) to those reported from Larsen Inlet. Other similar observations include that the ridges thin where they overprint the crests of associated elongate ridges, and that some of the fine-scale ridges are paired (e.g. Fig. 3b and c) (18). It is not possible to fully assess the wider geomorphological context of the data acquired beneath Pine Island Glacier ice shelf because those observations were acquired during single AUV transects which provide little lateral continuity of form.

\section{Recessional moraines}

Corrugation ridges have markedly different geomorphological characteristics compared to recessional moraines that are formed by the delivery and ice-pushing of sediment during shortlived re-advances of the grounding line during overall retreat (Table S1). Although small recessional moraines, which are often referred to as De Geer moraines and can be formed annually (52), are usually identified in assemblages of tens to hundreds of ridges that are a few meters high, they are typically sub-parallel to each other and less regularly spaced than tidally produced ridges. Recessional moraines have been identified mainly on Northern Hemisphere continental shelves and in fjords $(25,26,53)$ but have also been reported from Antarctic shelves and bays $(22-24,54-56)$.

\section{Alternative hypotheses for fine-scale ridge formation}

The squeezing of soft sediments into crevasses at the ice-sheet base during ice stagnation has been suggested as a possible mechanism for the formation of fine-scale ridges in the geological record $(18,50)$. However, the fine-scale ridges in Larsen Inlet (Figs. 2 and 3) clearly lack the characteristic rhombohedral plan-view geometry of crevasse-fill ridges, as well as their sharp crests and steep sides (26). It is possible that the fine-scale ridges are sediment waves formed by ocean currents, and this interpretation is favored by O'Brien et al. (51) for the features in Prydz Bay, East Antarctica. Although it is possible that ocean currents beneath ice shelves are modulated by tides, the formation of sediment waves would require the availability of coarse well-sorted sediment (18). We note that in sediment core VC318, which was acquired on the upper surface of the GZWs in Larsen Inlet, close to the surveyed area (Fig. 1a), $0.4 \mathrm{~m}$ of finegrained sediment interpreted to have been deposited in an open marine or sub-ice shelf setting distal from the grounding line, overlie $0.8 \mathrm{~m}$ of thick diamicton beds alternating with thin finegrained layers, which are interpreted as sub-ice shelf sediments deposited proximal to the grounding line. These grounding-line proximal sediments are underlain by $1.5 \mathrm{~m}$ of massive, matrix supported diamicton interpreted as subglacial soft till (11). 
Fig. S1.

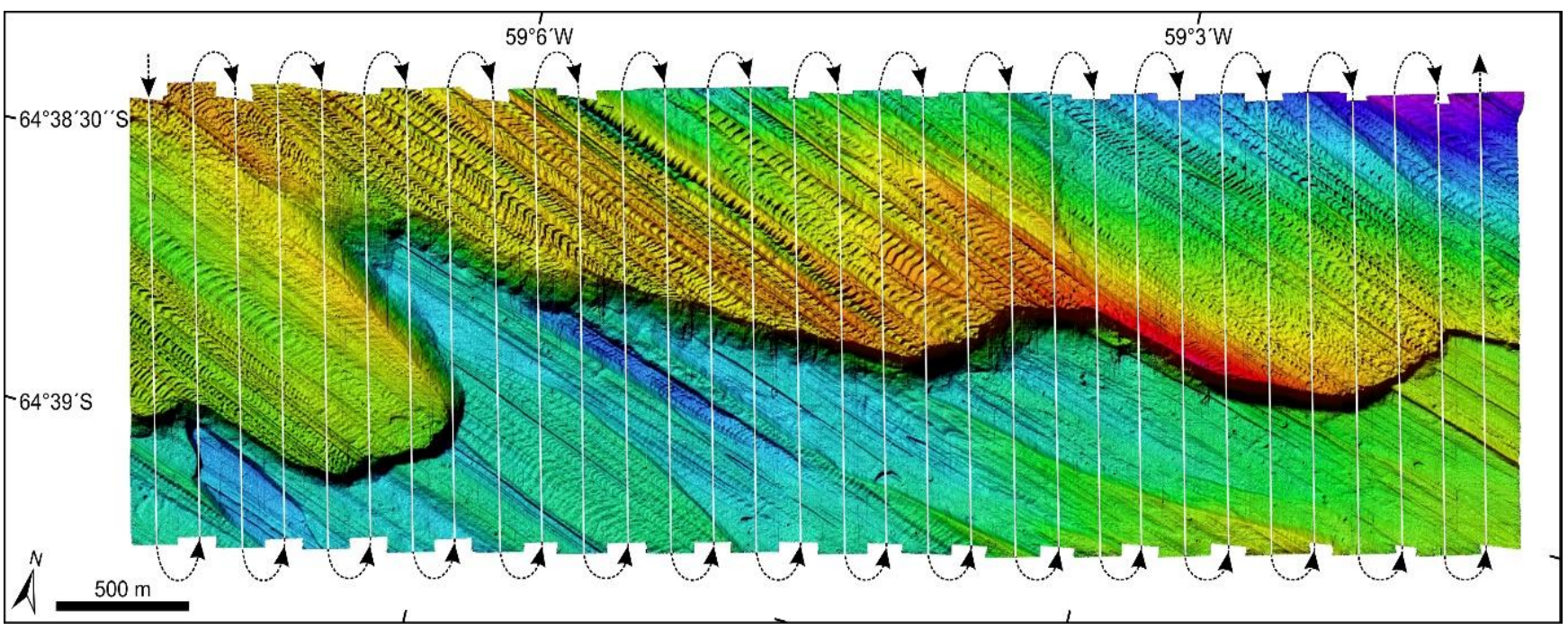

Figure S1. Map showing the track lines (white lines and black arrows) of the autonomous underwater vehicle (AUV) that acquired the multibeam and sub-bottom profiler data presented in this study. 
Table S1.

\begin{tabular}{|c|c|c|c|c|}
\hline & \multicolumn{3}{|c|}{$\begin{array}{l}\text { Corrugation ridges } \\
\text { (produced by the interaction of ice and tides at the seafloor) }\end{array}$} & \multirow{2}{*}{$\begin{array}{l}\text { Recessional } \\
\text { moraines } \\
\text { (produced by the } \\
\text { ice-pushing of } \\
\text { sediment during } \\
\text { short-lived re- } \\
\text { advances of the } \\
\text { grounding line) }\end{array}$} \\
\hline & $\begin{array}{l}\text { Produced by iceberg } \\
\text { keels, often in } \\
\text { mélange }\end{array}$ & $\begin{array}{l}\text { Produced by the } \\
\text { forward ploughing } \\
\text { of sub-ice shelf } \\
\text { keels }\end{array}$ & $\begin{array}{l}\text { Produced along the } \\
\text { grounding line } \\
\text { during grounding- } \\
\text { line retreat } \\
\text { ('ladder and rung } \\
\text { topography') }\end{array}$ & \\
\hline Ridge height & $0.2-3.4 \mathrm{~m}$ & $0.5-3 \mathrm{~m}$ & $\begin{array}{c}0.1-2 \mathrm{~m} ; \text { more } \\
\text { pronounced in } \\
\text { depressions } \\
\text { between MSGL }\end{array}$ & $0.5->10 \mathrm{~m}$ \\
\hline Ridge length & $\begin{array}{c}\text { Spans width of } \\
\text { iceberg ploughmark }\end{array}$ & $\begin{array}{l}\text { Spans width of sub- } \\
\text { ice shelf keel scour }\end{array}$ & $\begin{array}{c}\text { Laterally } \\
\text { continuous over } \\
\text { several kilometers }\end{array}$ & $\begin{array}{l}\text { Several hundred } \\
\text { meters to } \\
\text { kilometers }\end{array}$ \\
\hline Ridge spacing & $\begin{array}{l}\text { Regular to irregular; } \\
\text { tens to hundreds of } \\
\text { meters }\end{array}$ & $\begin{array}{c}\text { Remarkably } \\
\text { regular; tens to } \\
\text { hundreds of meters }\end{array}$ & $\begin{array}{c}\text { Remarkably } \\
\text { regular; several tens } \\
\text { of meters }\end{array}$ & $\begin{array}{l}\text { Irregular; tens of } \\
\text { meters to several } \\
\text { kilometers }\end{array}$ \\
\hline $\begin{array}{l}\text { Cross-sectional } \\
\text { geometry }\end{array}$ & $\begin{array}{c}\text { Symmetric or } \\
\text { asymmetric }\end{array}$ & $\begin{array}{c}\text { Symmetric or } \\
\text { asymmetric }\end{array}$ & $\begin{array}{l}\text { Often asymmetric } \\
\text { with steeper ice- } \\
\text { distal side; some } \\
\text { ridges are 'paired' }\end{array}$ & $\begin{array}{l}\text { Symmetric or } \\
\text { asymmetric with } \\
\text { steeper ice- } \\
\text { proximal side }\end{array}$ \\
\hline $\begin{array}{l}\text { Plan-view } \\
\text { geometry }\end{array}$ & Linear to convex & Linear to convex & $\begin{array}{l}\text { Linear to convex; } \\
\text { overprint MSGL }\end{array}$ & $\begin{array}{l}\text { Linear to sinuous; } \\
\text { continuous to } \\
\text { discontinuous }\end{array}$ \\
\hline $\begin{array}{c}\text { Wider } \\
\text { geological } \\
\text { context }\end{array}$ & $\begin{array}{l}\text { Confined within } \\
\text { iceberg ploughmarks }\end{array}$ & $\begin{array}{l}\text { Confined within } \\
\text { sub-ice shelf keel } \\
\text { scours }\end{array}$ & $\begin{array}{c}\text { Overprint MSGLs } \\
\text { on the low-gradient } \\
\text { upper surface of } \\
\text { GZWs }\end{array}$ & $\begin{array}{c}\text { Sometimes } \\
\text { overprint MSGL }\end{array}$ \\
\hline $\begin{array}{l}\text { Previous } \\
\text { interpretations } \\
\text { of corrugation } \\
\text { ridges in the } \\
\text { literature }\end{array}$ & $\begin{array}{l}\text { 'Washboard pattern' } \\
\text { (Barnes and Lien } \\
\text { (44); Lien et al. (45)) } \\
\text { 'Corrugation ridges' } \\
\text { (Jakobsson } \text { et al. } \\
\text { (17); Klages } \text { et al. } \\
\text { (46); Halberstadt et } \\
\text { al. (22); Jakobsson } \\
\text { and Anderson (47); } \\
\text { Smith et al. (19)) }\end{array}$ & $\begin{array}{c}\text { 'Corrugations' } \\
\text { (Graham et al. } \\
(18)) \\
\text { 'Corrugation } \\
\text { ridges' } \\
\text { (Klages et al. }(40) \text {; } \\
\text { Halberstadt et al. } \\
\text { (22); Smith et al. } \\
(19))\end{array}$ & $\begin{array}{c}\text { 'Washboard } \\
\text { moraines' } \\
\text { (Anderson, (57)) } \\
\text { 'Dunes' } \\
\text { (O'Brien } \text { et al. } \\
\text { (51)) } \\
\text { 'Corrugation } \\
\text { moraines' } \\
\text { (Shipp et al. }(50) \text { ) } \\
\text { This study }\end{array}$ & $\begin{array}{c}\text { 'Small marginal } \\
\text { moraines' } \\
\text { (Halberstadt et al. } \\
(22)) \\
\text { 'Recessional } \\
\text { moraines' } \\
\text { (Klages et al. (23, } \\
\text { 54); Simkins } \text { et } \\
\text { al. }(24,55) ; \\
\text { Batchelor } \text { et al. } \\
\text { (56)) }\end{array}$ \\
\hline
\end{tabular}

Table S1. Comparison of the geomorphological characteristics of corrugation ridges and recessional moraines on Antarctic continental shelves. 


\section{References}

(41) J. Evans, K. A. Hogan, "Grounding-zone wedges on the northern Larsen shelf, Antarctic Peninsula" in Atlas of Submarine Glacial Landforms: Modern, Quaternary and Ancient, J. A. Dowdeswell, M. Canals, M. Jakobsson, B. J. Todd, E. K. Dowdeswell, K. A. Hogan, Eds. (Springer, 2016), Geological Society, London, Memoirs, vol. 46, 237-238.

(42) C. Lavoie, E. W. Domack, E. C. Pettit, T. A. Scambos, R. D. Larter, H.-W. Schenke, K. C. Yoo, J. Gutt, J. Wellner, M. Canals, J. B. Anderson, D. Amblas, Configuration of the Northern Antarctic Peninsula Ice Sheet at LGM based on a new synthesis of seabed imagery. The Cryosphere 9, 613-629 (2015).

(43) J. M. Campo, J. S. Wellner, E. Domack, C. Lavoie, K.-C. Yoo, Glacial geomorphology of the northwestern Weddell Sea, eastern Antarctic Peninsula continental shelf: shifting ice flow patterns during deglaciation. Geomorphology 280, 89-107 (2017).

(44) P. W. Barnes, R. Lien, Icebergs rework shelf sediments to $500 \mathrm{~m}$ off Antarctica. Geology 16, 1130-1133 (1988).

(45) R. Lien, A. Solheim, A. Elverhøi, K. Rokoengen, Iceberg scouring and sea bed morphology on the eastern Weddell Sea shelf, Antarctica. Polar Research 7, 43-57 (1989).

(46) J. P. Klages, G. Kuhn, A. G. C. Graham, C.-D. Hillenbrand, J. A. Smith, F. O. Nitsche, R. D. Larter, K. Gohl, Palaeo-ice stream pathways and retreat style in the easternmost Amundsen Sea Embayment, West Antarctica, revealed by combined multibeam bathymetric and seismic data. Geomorphology 245, 207-222 (2015).

(47) M. Jakobsson, J. B. Anderson, "Corrugation ridges in the Pine Island Bay glacier trough, West Antarctica" in Atlas of Submarine Glacial Landforms: Modern, Quaternary and Ancient, J. A. Dowdeswell, M. Canals, M. Jakobsson, B. J. Todd, E. K. Dowdeswell, K. A. Hogan, Eds. (Springer, 2016), Geological Society, London, Memoirs, vol. 46, 265-266.

(48) K. Andreassen, M. C. M. Winsborrow, L. R. Bjarnadóttir, D. C. Rüther, Ice stream retreat dynamics inferred from an assemblage of landforms in the northern Barents Sea. Quaternary Science Reviews 92, 246-257 (2014).

(49) J. A. Dowdeswell, K. A. Hogan, "Huge iceberg ploughmarks and associated corrugation ridges on the northern Svalbard shelf" in Atlas of Submarine Glacial Landforms: Modern, Quaternary and Ancient, J. A. Dowdeswell, M. Canals, M. Jakobsson, B. J. Todd, E. K. Dowdeswell, K. A. Hogan, Eds. (Springer, 2016), Geological Society, London, Memoirs, vol. 46, 269-270.

(50) S. S. Shipp, J. S. Wellner, J. B. Anderson, "Retreat signature of a polar ice stream: subglacial geomorphic features and sediments from the Ross Sea, Antarctica" in GlacierInfluenced Sedimentation on High-Latitude Continental Margins, J. A. Dowdeswell, C. Ó Cofaigh, Eds. (Springer, 2002), Geological Society, London, Special Publications, vol. 203, 277-304.

(51) P. E. O’Brien, L. De Santis, P. T. Harris, E. Domack, P. G. Quilty, Ice shelf grounding zone features of western Prydz Bay, Antarctica: sedimentary processes from seismic and sidescan images. Antarctic Science 11, 78-91 (1999).

(52) M. Lindén, P. Möller, Marginal formation of De Geer moraines and their implications to the dynamics of grounding-line recession. Journal of Quaternary Science 20, 113-133 (2005).

(53) D. J. Burton, J. A. Dowdeswell, K. A. Hogan, R. Noormets, "Little Ice Age terminal and retreat moraines in Kollerfjorden, NW Spitsbergen" in Atlas of Submarine Glacial Landforms: Modern, Quaternary and Ancient, J. A. Dowdeswell, M. Canals, M. Jakobsson, 
B. J. Todd, E. K. Dowdeswell, K. A. Hogan, Eds. (Springer, 2016), Geological Society, London, Memoirs, vol. 46, 71-72.

(54) J. P. Klages, G. Kuhn, C.-D. Hillenbrand, A. G. C. Graham, J. A. Smith, R. D. Larter, K. Gohl, First geomorphological record and glacial history of an inter-ice stream ridge on the West Antarctic continental shelf. Quaternary Science Reviews 61, 47-61 (2013).

(55) L. M. Simkins, S. L. Greenwood, J. B. Anderson, Diagnosing ice sheet grounding line stability from landform morphology. The Cryosphere 12, 2707-2726 (2018).

(56) C. L. Batchelor, J. A. Dowdeswell, K. A. Hogan, R. D. Larter, E. Parsons, O. West, Processes and patterns of glacier-influenced sedimentation and recent tidewater glacier dynamics in Darbel Bay, western Antarctic Peninsula. Antarctic Science 31, 218-227 (2019).

(57) J. B. Anderson, Antarctic Marine Geology (Cambridge University Press, 1999). 